\title{
METHODOLOGICAL MATERIALS FOR INCLUSIVE EDUCATION - RESEARCH OPPORTUNITIES
}

\author{
Rasa Iesalniece \\ University of Latvia, Latvia \\ Agnese Gromova-Ķūrena \\ University of Latvia, Latvia
}

\begin{abstract}
There is a variety of methodological materials available nowadays; however, it might be difficult to evaluate whether the materials are applicable in inclusive education settings as there is a lack of specific criteria for evaluating methodological materials. From this topicality further research idea has arisen. The aim of the further research is to find out what useful and practically applicable methodological materials in inclusive education are. As there have not been developed theories on evaluating the methodological materials yet, the research would be based on the methodology of the grounded theory. The research base is 50 different methodological materials that are available in Latvia, collected within the Erasmus+ Project "MyHub - a one-stop-shop on inclusion practices, tools, resources and methods for the pedagogical staff at formal and non-formal educational institutions". In the result the product of the research would be the guidelines for inclusive education practitioners to enable the search for and selection of ready-made methodological materials and to encourage the development of new materials.
\end{abstract}

Keywords: inclusive education, methodological materials, evaluation of methodological materials, applicability of methodological materials.

\section{Introduction}

One of Sustainable Development Goals of the UN for 2030 is to provide inclusive and quality education and to promote lifelong learning opportunities (United Nations General Assembly, 2015). The project Competence-based Approach to Curriculum implemented by the National Centre for Education of the Republic of Latvia also emphasizes that an important principle of implementing the improved curriculum is the inclusive education approach, which also involves how to support teachers to implement inclusive education and how to improve their skills 
working with children with diverse learning needs (Skola [School2030], 2019).

It must be admitted that not only in Latvia the concept of inclusive education in pedagogical practice might seem intimidating and is a great challenge (O'Donnell, 2012, 69-70; Sandri, 2014; Tannenbergerova, 2013), because not all teachers have the necessary knowledge, skills and experience to provide inclusive education (Raščevska et al., 2017); therefore, various professional development courses, seminars and methodological materials are developed and offered (European Agency for Special Needs Education, 2012; European Agency for Special Needs and Inclusive Education, 2016, 2019; Beizitere \& Grumolte-Lerhe, 2020).

What is more, continuous professional development of pedagogues is a must enforced by law in Latvia, and inclusive education is stated among one of the general competencies of pedagogues (Noteikumi par [Regulations regarding]..., 2018).

Another current trend in nowadays education is open education, which incorporates resources, tools and practices through an open sharing model, thus improving access to and efficiency in education (Haigler \& Owens, 2018; Latvijas Universitāte, 2018). Combining the traditions of knowledge transfer and creation with the 21st century technologies and providing wide access to freely available educational resources, the development of new knowledge, ideas and skills is fostered. "Open" means not only the access, but also the ability to transform and to use the materials, information and networks to personalize education for individual users or to bring it together in a new way for large and diverse audience, such as students, educators, school leaders, researchers and members of the society (Latvijas Universitāte, 2018). Although the variety of educational resources available for teachers on the Internet is huge, it is a challenge to seize how useful and applicable the materials are, and not all the materials are easy to find.

The above mentioned has led to the research idea of the development of "The Guidelines for the Evaluation of Methodological Materials in Inclusive Education" within the collaboration between the students of the Master's study programme "Educational Treatment of Diversity" Rasa Iesalniece and Agnese Gromova-Kurrena and under the guidance of Dr.paed. Dita Nimante (University of Latvia). Both authors are the practitioners of the general comprehensive and special education. Agnese GromovaĶūrena's two previous Bachelor's researches are based on her experience and practice - applying the appropriate support measures and teaching methods (including multisensory strategies) to the students of the special education programmes in the general education school. Rasa Iesalniece's Bachelor's Thesis is a research of the development of a repository for methodological materials on the Internet, which corresponds to the idea of 
the MyHub project. The idea for the current research and the joint work of both authors arose within the Erasmus + project "MyHub - one-stop-shop on inclusion practices, tools, resources and methods for the pedagogical staff at formal and non-formal educational institutions" (MyHub, 2019) which has led to the conclusion that in order to be able to analyse the methodological materials, precise guidelines are needed, which would also serve as an aid in the development of further methodological materials for inclusive education.

Herewith the authors are presenting the idea of further research "The Guidelines for the Evaluation of Methodological Materials in Inclusive Education", the aim of which is to find out what useful and practically applicable methodological materials in inclusive education are.

\section{Description of proposed Research Project}

The guidelines based on certain criteria is the basis of any qualitatively developed materials and provide support for the implementation of new ideas, as well as promote the development of new methodological materials in inclusive education. Having searched for the guidelines for the evaluation of methodological materials in inclusive education that are currently available, it was concluded that no system for the evaluation of methodological materials in the context of inclusive education has been developed yet. On elementary level such search engine as Google Search (including Google Book and Google Scholar) was used, as to academic search - resources available on Primo Discovery (Library of the University of Latvia (UL) iCloud - UL subscribed and test-used online databases, UL Library's electronic catalogue and created databases (UL Database of Publications and History, UL Database of Graduation Papers)) and ScienceDirect were explored. During the search following keywords and their various combinations were used both in Latvian and English: development / criteria / evaluation / assessment (of) methodological materials / educational resources / course books (in) inclusive education / special (needs; development / mental / learning disorders / disabilities) education / global education.

Both in Latvian and in foreign languages there are criteria and guidelines for the development and evaluation of educational materials. There are also guidelines for developing methodological materials (VIAA [SEDA], 2010), as well as guidelines for the development and evaluation of digital materials (LICTA, 2016) and the evaluation of course books. However, no criteria to evaluate methodological materials for teachers and pedagogical professionals have been found. Therefore, the aim of the planned research is to develop guidelines based on certain criteria that would enable to distinguish if 
the provided materials can be considered methodological materials and what methodological materials are useful and practically applicable for teachers in inclusive education. These guidelines would facilitate the buildup of efficient system for the development of methodological materials in inclusive education, increasing the quality of their development, evaluation and systematization, as well as facilitating and promoting opportunities for teachers in the choice of the necessary methodological materials.

Within the framework of the "My HUB" project (MyHub, 2019), 50 different methodological materials available in Latvia have been collected and acquired during the period of July 2019 - January 2020. These materials cover such areas as global education, working with children with special needs (such as intellectual disabilities, visual and hearing impairments, behavioural disorders, learning disorders), managing inclusive classroom, i.e., materials that facilitate inclusive education in Latvia. The authors of the methodological materials are both different state organisations and groups of co-operate authors within various associations and projects. To mention some examples, the state institutions which have issued methodological materials in the cooperation with several authors are National Centre for Education of the Republic of Latvia (Bethere \& Lìdaka, 2013; Tereško \& Kondrova, 2013; Žalve \& Kursīte, 2013; Tūbele \& Šūmane, 2013; Prudņikova, 2019) and The State Inspectorate for Protection of Children's Rights (Koknese Boarding Primary School - Development Centre, 2019, Muceniece, 2018); there are also methodological materials developed by educational institutions and centres, e.g. Riga $1^{\text {st }}$ Special Boarding School - Developmental Centre (Cibin, Krauce, 2017), The Centre for Educational Initiatives (Tankersley, Brajkovic, 2016), which also collaborated with Preili Preschool "Pasacina [fairy tale]" (Center for Educational Initiatives, n.d.).

In order to analyse their applicability, as well as to summarize and structure them, it is necessary to establish certain criteria, which do not exist yet. Thus, the planned research cannot be based on previously developed theories, but it can be made according to the research methods of the grounded theory. Grounded theory is "an inductive, comparative methodology that provides systematic guidelines for gathering, synthesizing, analysing, and conceptualizing qualitative data for the purpose of theory construction" (Charmaz, 2001). The research of this kind is started with a wide range of questions on a specific topic and followed by the collection of the data according to the topic. The materials obtained in the data collection process are constantly reviewed, compared, contrasted, identifying common and different features, inductively developing a theory that explains the observations (Charmaz, 2001; DePoy, Gitlin, 2016). In other words, grounded theory research is based on the exploration of "social phenomena by looking at what people experience, what problems 
are present and how individuals go about resolving these issues," it is the inquiry of people to find and reflect on the patterns in these experiences (Engward, 2013). Grounded theory is an action approach where it is important to avoid assumptions and adopt more natural views of human action; it consists of several stages:

1. A "discovery" method at the first stage is the explanatory grounded theory - by studying the whole system with the help of rigorous set of procedures the researcher inductively gets at the real problems or issues in a system.

2. The operational theory informs what needs to be done to deal with the problem or issue of the system.

3. The action plan uses the practicalities of a particular system figure out how to set the operational theory in motion; at this stage it can be understood that some details of operational theory cannot be put into practice in real life.

4. The action is doing, bringing or realization of the action plan into practice.

5. Transformative learning - an ongoing process continuous discovering, learning, changing, adapting etc. (Simmons, 2006).

During the research it is planned to collaborate with teachers and the specialists and students of education, to find out what the determining criteria for the evaluation and development of useful and practically applicable materials are. The methods of the research are planned to be mixed both qualitative and quantitative. To start with, such qualitative methods as interviews with teachers and practitioners as well as discussions with future teachers groups could be carried out at the explanatory grounded theory study level. Next at the operational theory level such quantitative methods as questionnaires could be applied.

The research questions are as follows:

- what useful and practically applicable methodological materials are;

- what a methodological material should consist of;

- what criteria characterize a useful and practically applicable material;

- how proportionally long should the theoretical and practical parts of the methodological material be;

- what criteria increase the efficient applicability of the methodological material;

- what should the language of the methodological material be (scientific or simple).

The objectives of the research are:

- to get acquainted with the criteria used for the development and evaluation of educational materials; 
- to carry out the focus group (teachers, specialists and students of education) discussions and interviews to clarify the criteria for evaluating methodological materials;

- to develop the guidelines for the evaluation of methodological materials;

- to select the materials from the research base that are appropriate for inclusive education;

- to analyse the selected methodological materials according to the chosen criteria and developed guidelines.

Having partly carried out the first objective of the research of getting acquainted with the criteria for the development and evaluation of educational materials, it can be concluded that every methodological material must have certain criteria to be sufficiently functional and to accomplish the initial idea of reaching certain educational goal. The methodological material should be of good quality, accessible to all, easy to understand. Thoughtfully structured content facilitates the understanding and mastering of the methodological material, promotes purposeful and meaningful teaching and its management. This encourages the development of the guidelines that can provide the directions, analysis and development of methodological material for inclusive education, as the main purpose of the guidelines is to support teachers in implementing the curricula and learning content.

\section{Conclusions}

The first insight into the methodological materials available in Latvia gives an idea of the progress towards and means of promoting the quality of inclusive education in Latvia. It must be admitted that the variety of methodological materials gives and evidence of endeavours for creating an inclusive educational environment.

However, the accessibility and applicability of the methodological materials in practice, as well as the meaningfulness and quality of them are still to be explored and analysed, which could be carried out by the proposed research. The development of "The Guidelines for the Evaluation of Methodological Materials in Inclusive Education" could be not only the contribution to and support for teachers facilitating inclusive education setting, but also for other practitioners of inclusive education, authors of pedagogical materials, state institutions who plan the provision of methodological assistance in inclusive education, and such open education repository projects as "My Hub" (2019).

By developing the criteria for the evaluation of methodological materials, real and useful instructions of what a good quality materials are would be 
provided to a user by attracting the attention of the target audience. Thus, a concept for further development of methodological materials would be presented for of professionals who could bring the knowledge into practice. Certain criteria would also facilitate the categorization and organisation of materials in the repository of "MyHyb" project, which would enable a better accessibility and higher quality search of the necessary materials for broader audience.

\section{References}

Beizītere, I., Grumolte-Lerhe, I., Ziemane, I. \& Valtenbergs, V. (2020). Ieklaujošā izglītiba bèrniem ar speciālām vajadzïbām Latvijā [Inclusive education for children with special needs in Latvia]. Latvijas Republikas Saeima. Retrieved from: https://www.saeima.lv/ petijumi/Ieklaujosa_izglitiba_berniem_spec_vajadzibam_Latvija.pdf.

Bethere, D., Lìdaka, A., Plostniece, A., Ponomarjova, J., Striguna, S. (2013). Informativs materiāls vecākiem, kas audzina bērnus ar uzvedïbas traucējumie [Informative material for parents raising children with behavioral disorders]. Riga: National Centre for Education.

Center for Educational Initiatives, Preili pre-school educational institution "Pasacina" (n.d.). Iekḷajošu pasākumu cikls romu bèrniem un gimenēm un vinu vienaudžiem [Series of Inclusive Activities for Roma Children and Fmilies and Their Peers]. Jekabpils: Center for Educational Initiatives. Retrieved from: http://iic.lv/wp-content/uploads/2017/07/ Materials_pedagogiem_gala.pdf.

Charmaz, K. (2001). Grounded theory: Methodology and theory construction. In N. J. Smelser \& P. B. Baltes (Eds.), International encyclopedia of the social \& behavioral sciences (pp. 6396-6399). Amsterdam, New York: Elsevier. Retrieved from: https:// www.sciencedirect.com/science/article/pii/B0080430767007750.

Cibiņa, V., Krauce, A., Balabka, I., Pastore, E., Gžibovska, S. (2017). Matemātiskie jēdzieni un uzdevumi kompetenču pieejā. Metodiskais lìdzeklis [Mathematical Concepts and Tasks in the Competence Based Approach. Methodological Materials]. Riga: Riga Boarding Primary School - Development Centre. Retrieved from: https://visc.gov.lv/ specizglitiba/dokumenti/metmat/citi/mat_jedz_un_uzdevumi.pdf.

DePoy, E., Gitlin, L. N. (2016). Formulating Research Questions and Queries. In Introduction to Research (Fifth Edition). Understanding and Applying Multiple Strategies. Elsevier. Retrieved from: https://www.sciencedirect.com/topics/neuroscience/grounded-theory.

Engward, H. (2013). Understanding grounded theory. In: Scholarly Journals, Nurishing Standard (through 2013); London Vol. 28, Iss. 7, (Oct 16, 2013): 37. Retrieved from: http://datubazes.lanet.lv:2118/10.7748/ns2013.10.28.7.37.e7806.

European Agency for Development in Special Needs Education. (2012). Ieklaujošu skolotāju profils [Profile of Inclusive Teachers]. Odense, Denmark: European Agency for Development in Special Needs Education. Retriewed from: https://www.europeanagency.org/sites/default/files/profile_of_inclusive_teachers_lv.pdf.

European Agency for Special Needs and Inclusive Education. (2016). Financing of Inclusive Education: Mapping Country Systems for Inclusive Education. (S. Ebers old, ed.). Odense, Denmark.

European Agency for Special Needs and Inclusive Education. (2019). Teacher Professional Learning for Inclusion: Literature Review. (A. De Vroey, S. Symeonidou and A. Watkins, eds.). Odense, Denmark. 
Haigler, A., Owens, B. (2018). Open Up, Education! How open way learning can transform schools. Lanham : Rowman \& Littlefield.

Koknese Boarding Primary School - Development Center [The State Inspectorate For Protection Of Children's Rights] (2019). Uzvedïba kā skolēnu sasniegumus motivējošs factors [Behaviour as a Motivating Factor for Students' Achievement]. Retrieved from: https://drive.google.com/file/d/1wuYk8Me1Bv2JlXxvZx5cgBEMN-KtoPl2/view.

Latvijas Universitāte (2018). Atvērtā izglïtiba [Open Education]. Retrieved from: https:// www.napd.lu.lv/open-education/.

Latvijas Informācijas un komunikācijas tehnolog̣iju asociācija (LICTA) [Latvian Information and Communication Technology Association (LICTA)] (2016). Ieteikumi digitālo mācību lìdzekḷu un resursu izstrādei un novērtēšanai [Recommendations for the Development and Assessment of Digital Learning Tools and Resources]. Retrieved from: https://cfla. gov.lv/userfiles/files/8312_7_pielikums_DML_vadlinijas_LIKTA_08022019.pdf.

Muceniece, I. (2018). Iecietỉbas veicināšana izglïtibas iestādēe [Promoting Tolerance in an Educational Institution]. Riga: The State Inspectorate for Protection Of Children's Rights, Operations Department of Children's Hotline.

MyHub (2019). Tiešsaistes repozitorijs iekḷaujošām praksēm, resursiem, metodikām pedagogískā personāla lietošanai formālajā un neformālajā izglìtibāa [An online repository of inclusive practices, resources, methodologies for the use of teaching staff in formal and non-formal education]. Retrieved from: https://www.inclusion-hub.eu/?lang $=\mathrm{lv}$.

Noteikumi par pedagogiem nepieciešamo izglīî̉bu un profesionālo kvalifikāciju un pedagogu profesionālās kompetences pilnveides kārtību [Regulations regarding the education and professional qualifications required for teachers and the procedure for the improvement of teachers' professional competence] (2018). Ministru kabineta noteikumi Nr. 569. [Regulations of the Cabinet of Ministers No. 569] Ministru kabinets. Retrieved from: https://likumi.lv/ta/id/301572-noteikumi-par-pedagogiemnepieciesamo-izglitibu-un-profesionalo-kvalifikaciju-un-pedagogu-profesionalaskompetences-pilnveides.

O’Donnell, M. (2012) Teachers' Efficacy Beliefs for Including Pupils with Special Educational Needs in Irish Mainstream Primary Schools. In Day, T. and Travers, J. (ed.) Special and Inclusive Education : A Research Perspective. Bern: Peter Lang AG. Retrieved from: https:// datubazes.lanet.lv:2085/readonline/9783035303452.

Prudnikova, I. (2019). Metodiskie ieteikumi speciālistiem (psihologs, logopēds, speciālais pedagogs) dokumentu sagatavošanai [Methodological recommendations for specialists (psychologist, speech therapist, special pedagogue) for the preparation of documents]. Riga: National Centre for Education. Retrieved from: https://visc.gov.lv/specizglitiba/ dokumenti/metmat/metiet_specialistiem_dok_sagatavosanai.pdf.

Raščevska, M., Nīmante, D., Umbraško, S., Šūmane, I., Martinsone, B. \& Žukovska, I. (2017). Pētījums par bērniem ar speciālām vajadzībām sniedzamo atbalsta pakalpojumu izmaksu modeli iekḷaujošas izglìtības îstenošanas kontekstā [Study on the financial model for support services for children with special needs in the context of the implementation of inclusive education in Latvia]. Retrieved from http://www.izm.gov.lv/images/ izglitiba_visp/IZMiepirkumamLUPPMFgalaparskats08122017.pdf (30.04.2020).

Sandri, P. (2014) Integration and inclusion in Italy. Towards a special pedagogy for inclusion. ALTER. European Journal of Disability Research 8. S. 1.: Elsevier Ltd. Retrieved from: https://www.sciencedirect.com/science/article/pii/S1875067214000194. 
Skola2030 [School2030] (2019). Atbalsts mācibu pieejas mainai [Supporting a change in the approach to learning and teaching]. Retrieved from: http://www.skola2030.lv/lv/ par-projektu.

Simmons, O. E. (2006). Some Professional and Personal Notes on Research Methods, Systems Theory, and Grounded Action. World Futures, 62, 7, 481-490, Retrieved from: https://doi.org/10.1080/02604020600912772.

Tankersley, D., Brajkovic, S., Handzar, S., Rimkiene, R., Sabaliauskiene, R., Trikic, Vonta, Z. T (2016). Kvalitativia pedagoǵija: zināšanas praksēe. Kvalitativis pedagoǵijas principi un to istenošanas vadlinijas [Qualitative pedagogy: knowledge in practice. Principles of quality pedagogy and guidelines for their implementation]. (s. 1.): Center for Educational Initiatives; International Step by Step Association (2011). Retrieved from: http://iic.lv/wp-content/uploads/2018/07/Kvalitativa_pedagogija_zinasanas_prakse_ IESKATS.pdf.

Tannenbergerova, M. (2013). Equality in Educational System as a Challenge for Future Teachers. In Odabasi, F. (ed.) Procedia - Social and Behavioral Sciences. S. 1.: Elsevier Ltd. Retrieved from: https://www.sciencedirect.com/science/article/pii/ S1877042813033405

Tereško, A., Kondrova, A., Rozenfelde, M., Želve, I. (2013). Bērns ar garīgās attïstibas traucējumiem gimene $\bar{e}$ [A child with a mental disability in the family]. Riga: National Centre for Education.

Tūbele, S., Šūmane, I., Burčaka, M., Laganovska, E., Landra, T. (2013). Atbalsta materiāls skolotājiem darbam ar interaktīvu mācību materiālu valodas prasmju veidošanai un attistīšanai skolēniem ar speciālām vajadzïbām [Support materials for teachers to work with interactive teaching material for the development of language skills for students with special needs]. Riga: National Centre for Education.

United Nations General Assembly (2015). Rezolūcija: Mūsu pasaules pārveidošana: ilgtspējigas attistibas programma 2030. gadam. Pārresoru koordinācijas centrs. ANO ilgtspējīgas attīstības mērkii [Resolution: Transforming our world: the 2030 Agenda for Sustainable Development. Interdepartmental Coordination Center. UN Sustainable Development Goals]. Retrieved from: https://www.pkc.gov.lv/lv/attistibas-planosana/ ano-ilgtspejigas-attistibas-merki.

Valsts izglīīibas attīstības aǵentūra (VIAA) [SEDA - State Education Development Agency] (2010). Vadlīnijas mācību metodisko materiālu izstrādei [Guidelines for the Development of Teaching Materials]. Retrieved from: http://sf.viaa.gov.lv/library/ files/original/12113_maacibu_metodisko_materiaalu_vadliinijas.doc.

Želve, I., Kursīte, I., Strazdiņa U. (2013). Bērns ar kohleāro implantu gimenē [A child with a cochlear implant in a family]. Riga: National Centre for Education.

Note: This article has been developed under the framework of "Erasmus + Project "MyHub - a one-stop-shop on inclusion practices, tools, resources and methods for the pedagogical staff at formal and non-formal educational institutions". 